\title{
Regulation of human villous trophoblast by insulin-like growth factors and insulin-like growth factor-binding protein-1
}

\author{
F A Hills, M G Elder, T Chard ${ }^{\mathbf{1}}$ and M H F Sullivan \\ Department of Obstetrics and Gynaecology, Institute of Reproductive and Developmental Biology, Wolfson and Weston Centre for Family Health, \\ Imperial College London, Hammersmith Hospital, Du Cane Road, London W12 ONN, United Kingdom \\ ${ }^{1}$ Department of Obstetrics and Gynaecology, St Bartholomew's and The Royal London School of Medicine and Dentistry, London EC1A 7BE, United Kingdom \\ (Requests for offprints should be addressed to M H F Sullivan; Email: mark.sullivan@imperial.ac.uk)
}

\begin{abstract}
Many studies have implicated the insulin-like growth factors (IGFs) and insulin-like growth factor-binding protein-1 (IGFBP-1) in the control of the feto-maternal interface of human pregnancy, but many of the data are from cell lines derived from primary trophoblast or from extravillous trophoblast. We have obtained highly enriched villous cytotrophoblast (VCT) from first trimester and term human placentae, and investigated the effects of IGF-I, IGF-II and phosphoisoforms of IGFBP-1. First trimester villous trophoblast cells were regulated by all these factors. IGF-II increased cell numbers $3 \cdot 5$-fold after $96 \mathrm{~h}$ in culture, and IGF-I had less effect $(1 \cdot 5$-fold increase) (both $P<0 \cdot 05)$. IGF-II also had a greater effect on the levels of matrix metalloproteinase (MMP)-2 and MMP-9. Phosphorylated and non-phosphorylated isoforms of IGFBP-1 added alone increased cell numbers
\end{abstract}

and MMP levels $(P<0 \cdot 05)$. IGFBP-1 did not modify the effects of IGF-II on cell numbers or on MMP production. Term VCT numbers and MMP production in vitro were unaffected by IGFs $(P>0 \cdot 05)$. Cell numbers were increased only by $100 \mathrm{nM}$ IGFBP-1 isoforms $(P<0 \cdot 05)$, whereas MMP levels released from term cells were optimally increased by $1-10 \mathrm{nM}$ IGFBP-1. Overall, our data show that IGFs regulate only first trimester, but not term, VCT. IGFBP-1 regulates VCT from both gestations, but the effects are concentration and end-point specific. In particular, first trimester cell numbers are more affected by low levels of IGFBP-1, whereas high levels of IGFBP-1 are needed to increase MMP and the converse applies to term VCT; low levels of IGFBP-1 have more effect on MMP levels.

Journal of Endocrinology (2004) 183, 487-496

\section{Introduction}

Proper development of the human placenta is essential if normal pregnancy is to be maintained. This includes growth of the placenta, differentiation of the trophoblast and vascular systems, invasion of extravillous cytotrophoblast (EVCT) to form anchoring villi and remodelling of the uterine maternal vasculature to provide adequate nutrition for the rapid fetal growth in the second half of pregnancy. Defects in these processes, which lead to insufficient trophoblast growth and invasion, are associated with some of the major pregnancy complications, including fetal growth restriction, pre-eclampsia and early pregnancy loss (Brosens et al. 1972, Robertson et al. 1975, Teasdale 1989, Hustin et al. 1990). Furthermore, fetal growth restriction in utero is associated with an increased risk of cardiovascular disease in adult life (Barker et al. 1993). Conversely, excessive trophoblast growth characterises molar pregnancies and choriocarcinomas, and complications of pregnancy such as placenta increta, placenta accreta and placenta percreta are linked to increased invasion of trophoblast into the myometrium during pregnancy (Morison 1978, Paradinas \& Fisher 1995).

The control of human trophoblast functions is not well understood, despite the importance of these cells to pregnancy. Very many of the known growth factors and cytokines are expressed at the feto-maternal interface in fetal placenta, or in maternal decidua (Rice \& Chard 1998); this also applies to the receptors which mediate the effects of these potential regulators (Sharkey et al. 1995, Sanchez-Cuenca et al. 1999). There seem to be few pathways of regulation unique to pregnancy, but rather a complex series of factors which may be involved. A general paradigm has been derived from murine pregnancy, that fetal (paternally derived) factors are concerned primarily with increasing the size and development of the placenta and fetus, whereas maternal factors act in the opposite sense to restrain growth (Barton et al. 1985, Surani et al. 1987). This is supported by in vitro data from human pregnancy tissues, which show that proliferating placentally derived cells support their own growth and that this was inhibited by decidual products (Lewis et al. 1993). 
Candidate trophoblast growth factors include the insulinlike growth factors (IGFs) (Han et al. 1996), and decidual inhibitors may include insulin-like growth factor-binding protein-1 (IGFBP-1) (Rutanen et al. 1985, Pekonen et al. 1988 ) as well as transforming growth factor- $\beta$ (TGF- $\beta$ ) (Graham \& Lala 1992, Graham et al. 1992). A series of studies have not only confirmed that changes in the IGF-IGFBP-1 balance are linked to complications of pregnancy such as fetal growth restriction and preeclampsia (Howell et al. 1989, Giudice et al. 1995, Anim-Nyame et al. 2000), but have also shown that in a variety of model systems IGFs and IGFBP-1 have direct effects on trophoblast-derived cell proliferation and invasion (Maruo et al. 1995, Hamilton et al. 1998, McKinnon et al. 2001, Chakraborty et al. 2002).

IGF-I and IGF-II are single chain polypeptides, each $7 \cdot 5 \mathrm{kDa}$, which promote growth and differentiation in a variety of cell types (Jones \& Clemmons 1995). Their effects are mediated through specific receptors (insulinlike growth factor receptors (IGFRs)-I and -II), but our understanding of the roles of the receptors is incomplete. IGF-II binds most avidly to IGFR-II (Nielsen 1992), but this receptor has a short intracellular domain which has limited coupling to signal transduction systems; it may interact with inhibitory G-proteins (Okamoto \& Nishimoto 1991), but it is not clear whether this mediates all the effects of IGF-II. However, this growth factor can also bind to and activate IGFR-I, although with a lower affinity than IGF-I (Steele-Perkins et al. 1988). A further complication in the understanding of the IGF-IGFBP system is that while the binding proteins generally limit the effects of IGFs (Hills \& Chard 1995), they may synergise with them (Jones et al. 1993a). Furthermore, IGFBP-1 can bind to the Arg-Gly-Asp sequence of the fibronectin receptor $\left(\alpha_{5} \beta_{1}\right)$ and directly modulate cell function independently of IGFs (Jones et al. 1993b, Gleeson et al. 2001). Both the direct and IGF-related effects of IGFBP-1 may be affected by the degree of phosphorylation (Jones et al. 1991), which affects the affinity of the binding protein for its targets.

The primary aim of our study was to investigate the impact of the IGF-IGFBP-1 axis on the biology of human villous cytotrophoblast (VCT). It should be pointed out that many of the previous investigations have used EVCT (Bischof et al. 1995, Choy \& Manyonda 1998, Irwin \& Guidice 1998), cell lines derived from primary EVCT (Graham et al. 1993, Li \& Zhuang 1997, Hamilton et al. 1998, McKinnon et al. 2001, Chakraborty et al. 2002), immortalised cells (Lewis et al. 1996, Lala et al. 2002), or choriocarinomas (Ritvos et al. 1988, Librach et al. 1991). In the studies presented here we have: (a) developed the methods needed to isolate highly enriched primary first trimester and term VCT; (b) determined the effects of IGF-I, IGF-II and IGFBP-1 phosphoisoforms on VCT numbers in vitro; (c) investigated the effects of these same factors on the production of matrix metalloproteinase enzymes (MMPs). These are commonly used as surrogate markers for trophoblast invasiveness - the gelatinases (MMP-2 and MMP-9) have particularly been implicated in trophoblast invasion, and have been investigated thoroughly in human EVCT (Librach et al. 1991, Bischof et al. 1995).

\section{Materials and Methods}

\section{Tissue samples}

Samples of normal first trimester placental tissues were obtained after termination of pregnancy between 8 and 12 weeks gestation. Term placental tissues were obtained after delivery by elective Caesarean section prior to labour. Consent for the use of the tissues was obtained from the patients in accordance with the approval of Hammersmith Hospitals NHS Trust Ethics Committee. Twenty-five tissues of each type were used for the experiments described, as not all studies could be repeated on each cell preparation.

\section{Preparation of primary villous cytotrophoblast (PVCT) cultures}

The procedure to isolate VCT was essentially the same for first trimester and term tissues. Villous tissue was carefully dissected and incubated with Hank's balanced salt solution (Life Technologies, Paisley, UK) without calcium or magnesium, but also containing 0.025 M HEPES and $0 \cdot 125 \%(\mathrm{w} / \mathrm{v})$ trypsin 250 (Difco, Detroit, MI, USA) at $37^{\circ} \mathrm{C}$ for $40 \mathrm{~min}$ with regular vigorous shaking. The supernatant, containing isolated cells, was removed and further trypsin activity was stopped by addition of $5 \mathrm{ml}$ heat-inactivated, mycoplasma-screened fetal bovine serum (Helena Biosciences, Sunderland, UK). The remaining trophoblast tissue then underwent two further digestions under the same conditions. Supernatants were then pooled and passed through a $70 \mu \mathrm{m}$ sterile cell strainer (Becton Dickinson) to remove any non-digested tissue. The cell suspension was centrifuged at $1600 \mathrm{~g}$ for $20 \mathrm{~min}$ through a $40 \%$ percoll solution. Trophoblast cells were collected from the percoll/medium interface and cell debris and erythrocytes that had migrated through the percoll were discarded.

VCT were separated from other cell types by negative immunoselection with a monoclonal antibody W6/32 (Dako, High Wycombe, UK) that recognises epitopes common to human leucocyte antigen (HLA) class I antigens (Lata et al. 1992). Initially, cells were incubated with $20 \%(\mathrm{v} / \mathrm{v})$ rat serum in a $\mathrm{pH} 7 \cdot 4$ buffer comprising $50 \mathrm{mM}$ PBS, $0.5 \%(\mathrm{w} / \mathrm{v})$ BSA and $2 \mathrm{mM}$ EDTA for $20 \mathrm{~min}$ at $4{ }^{\circ} \mathrm{C}$ with constant shaking. Cells were then washed in buffer and incubated for $1 \mathrm{~h}$ at room temperature with mouse anti-HLA class I antigen (clone W6/32) at a concentration of approximately $1 \mu \mathrm{g}$ per $10^{6}$ cells in a 
total volume of $0.5 \mathrm{ml}$ buffer. After further washing the cells were incubated with $10 \%(\mathrm{v} / \mathrm{v})$ rat anti-mouse IgG magnetic microbeads (Miltenyi Biotec, Bisley, UK) for $30 \mathrm{~min}$ at room temperature. The cell suspension was then passed through a magnetic separation column and cells not expressing HLA class 1 antigens were eluted with $15 \mathrm{ml}$ buffer. After further washing cells were plated out into 96-well plates (approximately 20000 cells/well) in RPMI containing $2 \mathrm{mM}$ L-glutamine, penicillin $(100 \mathrm{IU} / \mathrm{ml})$ and streptomycin $(100 \mu \mathrm{g} / \mathrm{ml})$ supplemented with $10 \%$ FCS in an atmosphere containing $5 \% \mathrm{CO}_{2}$.

\section{Immunostaining}

The purity of the primary VCT was assessed by immunostaining. Cells in suspension were centrifuged onto glass slides at 500 r.p.m. for $3.5 \mathrm{~min}$ at room temperature in a Cytospin centrifuge and then stained for the presence of a specific trophoblast cell cytoskeletal marker cytokeratin 7 (Haigh et al. 1999) and for vimentin, a marker of stromal cells, using an avidin-biotin complex (ABC) detection system (Vector Laboratories, Burlingame, CA, USA). Cells were fixed in acetone:methanol (1:1) for $5 \mathrm{~min}$ and incubated for $30 \mathrm{~min}$ with a $10 \%$ hydrogen peroxide solution (in methanol) for 30 min to quench any endogenous peroxidase activity. After washing with PBS cells were incubated for $20 \mathrm{~min}$ with normal goat serum (1 in 67 dilution). Cells were washed twice with PBS and then incubated with a monoclonal antibody $(50 \mu \mathrm{l}, 1$ in 25 dilution) to cytokeratin 7 or vimentin (Dako) for $1 \mathrm{~h}$. Cytokeratin 7 or vimentin positive cells were visualised by further incubations with biotinylated goat anti-mouse IgG, HRP-labelled ABC and diaminobenzidine according to manufacturers' instructions. Cells were then lightly counterstained with Ehrlich's Haematoxylin (Merck, Poole, UK).

\section{Effect of IGFs and IGFBP-1}

Primary VCT were plated out at a concentration of approximately 20000 cells/well in 96-well plates in RPMI containing $2 \mathrm{mM}$ L-glutamine, penicillin (100 $\mathrm{IU} / \mathrm{ml})$ and streptomycin $(100 \mu \mathrm{g} / \mathrm{ml})$ supplemented with 10\% FCS in an atmosphere containing 5\% $\mathrm{CO}_{2}$. After overnight incubation the medium was changed to serum-free and was supplemented with IGF-I or IGF-II (Peninsular Laboratories, St Helens, UK: 0, 1, 10 and $100 \mathrm{nM})$ in the presence or absence of $1 \mathrm{nM}$ phosphorylated or dephosphorylated IGFBP-1 (Sigma, Poole, UK), or with phosphoisoforms of IGFBP-1 only $(0 \cdot 1,1,10$, $100 \mathrm{nM}$ ), and incubated for a further $96 \mathrm{~h}$ with a change of medium after $48 \mathrm{~h}$ incubation. The IGFBP-1 preparations were $\geq 95 \%$ pure with the remaining $\geq 5 \%$ comprising other IGFBP-1 isoforms. Triplicate wells were run for each treatment and experiments were repeated at least three times.

\section{Cell numbers}

At the end of the experiments the medium was removed from the cells, which were stored at $-20{ }^{\circ} \mathrm{C}$ until assay for cell numbers. This method relies on the reduction of a synthetic tetrazolium compound, 3-(4,5-dimethylthiazol2-yl)-5-(3-carboxymethoxyphenyl)-2-(4-sulphophenyl)2H-tetrazolium, inner salt (MTS; Promega UK Ltd) by $\mathrm{NADPH}$ or NADH produced by dehydrogenase enzymes in metabolically active cells. Medium was removed from cells at the end of each experiment and replaced with $100 \mu \mathrm{l}$ fresh medium and $20 \mu \mathrm{l}$ MTS reagent. After $2 \cdot 5 \mathrm{~h}$ incubation the $\mathrm{A}_{450}$ was determined. Cell number was determined by comparing absorbance from each well with that from wells containing a known number of cells.

\section{Detection of MMP-2 and MMP-9}

MMP-2 and MMP-9 activities were detected by gelatinase zymography as previously described (Graham et al. 1993). Media collected from IGF and IGFBP-1 stimulation experiments were mixed in a $4: 1$ ratio with SDS-PAGE loading buffer comprising $300 \mathrm{mmol} / 1$ Tris (pH 6.8), 50\% (v/v) glycerol, 10\% (w/v) SDS and $0 \cdot 1 \%$ bromophenol blue. Proteins were separated by discontinuous SDSPAGE using a $12 \%$ resolving gel containing $1 \mathrm{mg} / \mathrm{ml}$ gelatin under non-reducing conditions. Loading volumes were adjusted to take into account differences in cell number following incubation with different concentrations of IGFs and IGFBP-1.

Gels were washed twice in $2 \cdot 5 \%(\mathrm{v} / \mathrm{v})$ Triton X-100 and then incubated for $18 \mathrm{~h}$ at $37^{\circ} \mathrm{C}$ in zymography digestion buffer $(5 \mathrm{mmol} / \mathrm{l}$ Tris, $20 \mathrm{mmol} / 1 \mathrm{NaCl}$ and $0.5 \mathrm{mmol} / 1 \mathrm{CaCl}_{2}$ ). Gels were immersed in staining solution comprising $0.5 \%$ Coomassie blue-G in $30 \%$ methanol and $10 \%$ acetic acid for $2 \mathrm{~h}$ at room temperature and then destained in staining solution with the Coomassie blue omitted. MMP activity was seen as clear areas within the gel where the gelatin substrate had been hydrolysed by gelatinase activity.

\section{Quantification of MMP activity}

This was accomplished using image analysis software inherent in Adobe Photoshop. The process is described briefly below. For each lane in a gel the area containing all MMP activity was selected and the mean pixel brightness calculated automatically. Data were expressed as a percentage of the control (unstimulated) value. For MMP-2 and MMP-9 this process was repeated, except that only the area of gel representative of each individual MMP was used for the mean brightness calculations. Again the data were expressed as a percentage of the unstimulated value. This process is necessary because levels of the MMPs in the samples are not equivalent, and this separation allows the detection of changes in any MMP present at low levels that may be lost in the total assessment of activity. 
Statistical methods

All experiments were repeated at least three times. The data are expressed as mean \pm S.E.M. for replicate experiments. Because of the variability in baseline cell numbers, in experiments where the effects of IGFs and IGFBP-1 were studied the cell number was expressed as the percentage of the control level from each experiment. Changes in cell numbers were compared by one-way analysis of variance (ANOVA) and the Bonferroni/Dunn test was used to determine variation within each group.

\section{Results}

Immunocytochemistry of primary villous cytotrophoblast

First trimester and term placentae were digested to produce mixed single-cell suspensions which contained cells positive for cytokeratin $7(78 \cdot 1 \pm 2 \cdot 3 \%$, trophoblast), HLA $(32 \cdot 6 \pm 2 \cdot 4 \%)$ and vimentin $(19 \cdot 1 \pm 2 \cdot 9 \%)$. These preparations were enriched for VCT by removal of all cells which express HLA class 1 antigens, as described in Materials and Methods. After this procedure, 98.9 $\pm 0 \cdot 3 \%$ $(n=4)$ of the cells were cytokeratin 7 positive and therefore of trophoblast origin. These preparations contained few HLA+ $(1 \cdot 3 \pm 0 \cdot 4 \%)$ and vimentin+ $(1 \cdot 1 \pm 0 \cdot 7 \%)$ cells. Similar data were obtained from first trimester and from term tissues.

\section{Effect of IGFs and IGFBP-1 on cell numbers}

Preliminary studies showed small positive effects of IGFs on numbers of primary first trimester VCT after $48 \mathrm{~h}$ of culture and greater effects after $96 \mathrm{~h}$ (data not shown). The longer incubation was therefore used in all remaining experiments. These studies also showed that there was a variable decrease in cell numbers (of 10\%-40\%) associated with the first change of medium (after $24 \mathrm{~h}$ of culture), but no change in cell numbers thereafter under basal culture conditions.

IGF-I increased first trimester VCT numbers after $96 \mathrm{~h}$ of culture (Fig. 1a); the greatest effect was a 1.5-fold increase with $100 \mathrm{nM}$ IGF-I. IGF-II also had dosedependent effects on first trimester VCT numbers, but the optimal dose was lower $(10 \mathrm{nM})$, and the mean effect greater (3.5-fold) (Fig. 1a). Under the same conditions, numbers of term VCT were unaffected by both IGFs (Fig. 1b).

The addition of phosphorylated IGFBP-1 (pIGFBP-1) or unphosphorylated IGFBP-1 (nIGFBP-1) also increased first trimester VCT numbers after $96 \mathrm{~h}$ of culture (Fig. 2a), and the greatest effect was with $1 \mathrm{nM}$ binding proteins. Only $100 \mathrm{nM}$ of both IGFBP-1s significantly increased numbers of term VCT in vitro (Fig. 2b). Co-incubation of first trimester VCT with IGF-II and IGFBP-1 phospho-
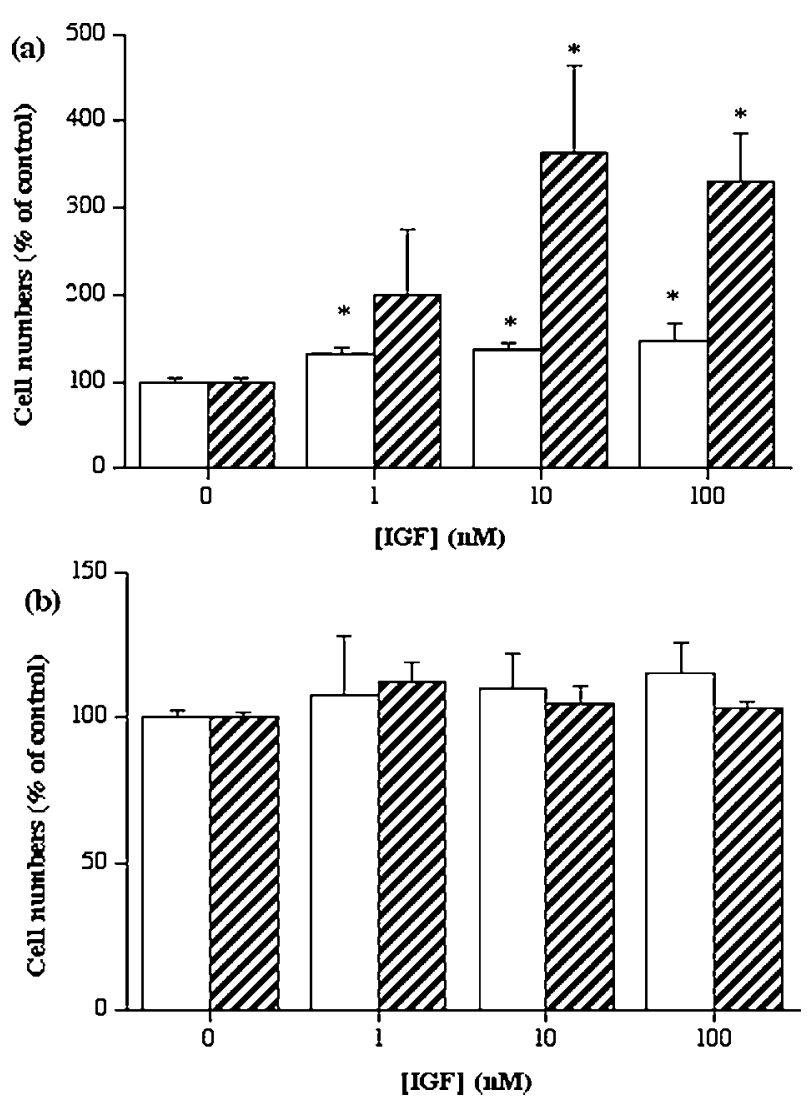

Figure 1 Numbers of enriched VCT from (a) first trimester or (b) term placenta following incubation with IGF-I ( $\square$ ) or IGF-II (hatched). Data are means \pm S.E.M. $(n=5) .{ }^{*} P<0 \cdot 05$ vs control (medium alone).

isoforms showed that neither form of IGFBP-1 inhibited the effects of IGF-II (Fig. 2c) on cell numbers.

\section{Effect of IGFs and IGFBP-1 on MMP-2 and MMP-9 secretion}

Both MMP-2 and MMP-9 could be detected in the culture medium from first trimester and term VCT and IGF-II seemed to increase levels of both MMPs, visualised as larger clear areas in the zymography gels (Figs $3 \mathrm{a}$ and $\mathrm{b}$ ). We determined total levels of MMP-2 activity plus MMP-9 activity, as well as the activity of individual MMPs, as described in the Materials and Methods section. The levels of MMP-2 and MMP-9 activity varied between different cell preparations, so data are expressed as a ratio to the corresponding controls.

In first trimester VCT, all the factors studied (IGF-I, IGF-II, nIGFBP-1 and pIGFBP-1) increased total MMP levels (Fig. 4a) and generally the greatest effects were observed at $100 \mathrm{nM}$ peptide. MMP-2 was increased by IGF-II and pIGFBP-1 (Fig. 4b), while IGF-I and nIGFBP-1 had numerically similar effects that did not 

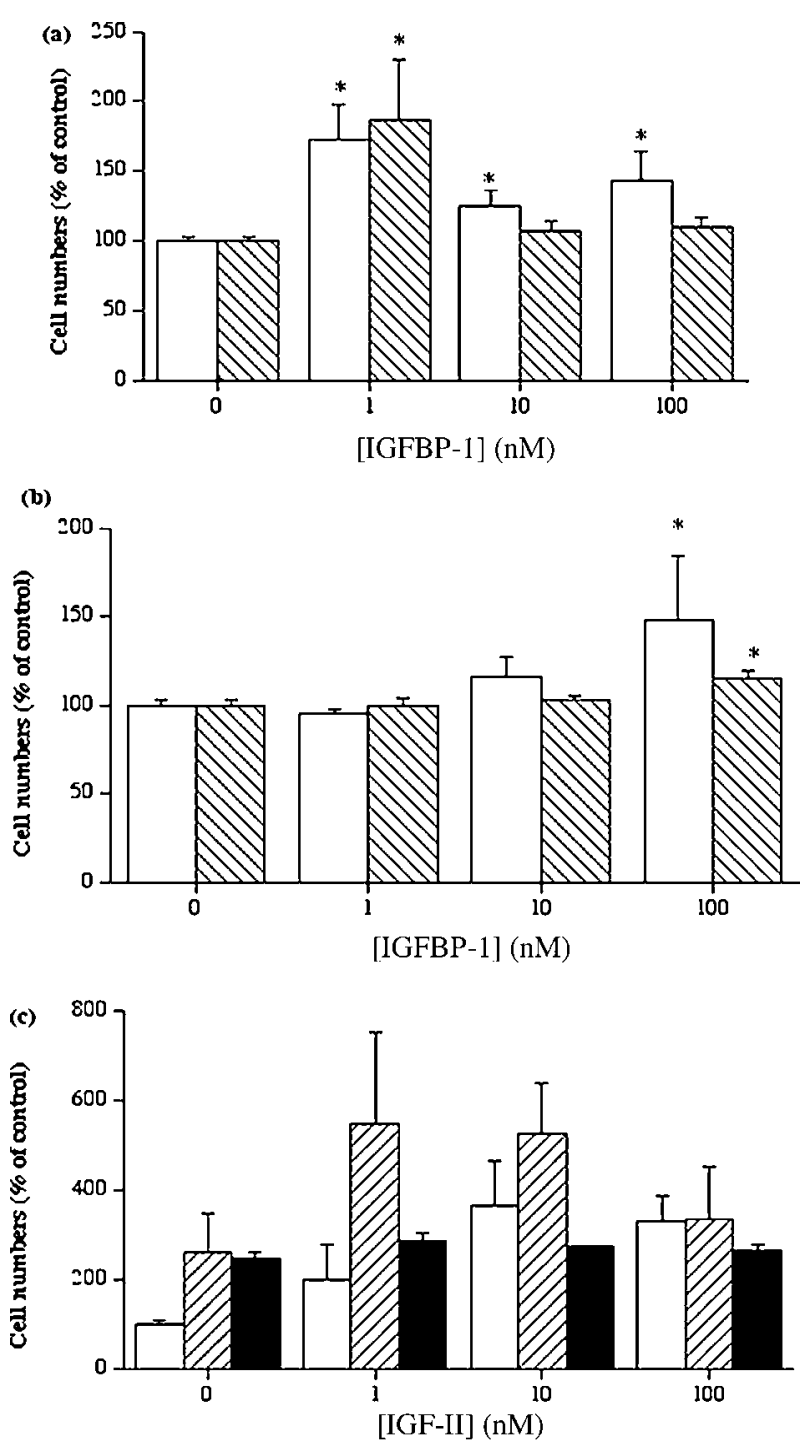

Figure 2 Numbers of enriched VCT from (a) first trimester or (b) term placenta following incubation with phosphorylated $(\square)$ or non-phosphorylated (hatched) IGFBP-1. ${ }^{*} P<0.05$ vs control (medium alone). In (c) first trimester VCT cells were co-incubated with IGF-II (concentrations as shown) ( $\square$ ), IGF-II+pIGFBP-1 $(1 \mathrm{nM})$ (hatched) or IGF-II+nIGFBP-1 (1 nM) (ם). All data are means \pm S.E.M. $(n=4)$. In (c) all additions of IGF-II and IGFBP-1 (alone or in combination) increased cell numbers $(P<0 \cdot 05$ vs. no addition), but there was no additional effect of co-incubation compared with IGF-II alone.

reach statistical significance. MMP-9 was increased by the highest dose of all four peptides, although pIGFBP-1 had the greatest effect (Fig. 4c).

In term VCT, IGF-II had a modest effect on total levels of MMP activity (Fig. 5a) at a concentration of $100 \mathrm{nM}$. Both isoforms of IGFBP-1 had more potent effects (Fig. $5 \mathrm{a})$ at lower concentrations (1-10 nM), and IGF-I was without significant effect. Changes in MMP-2 activity in
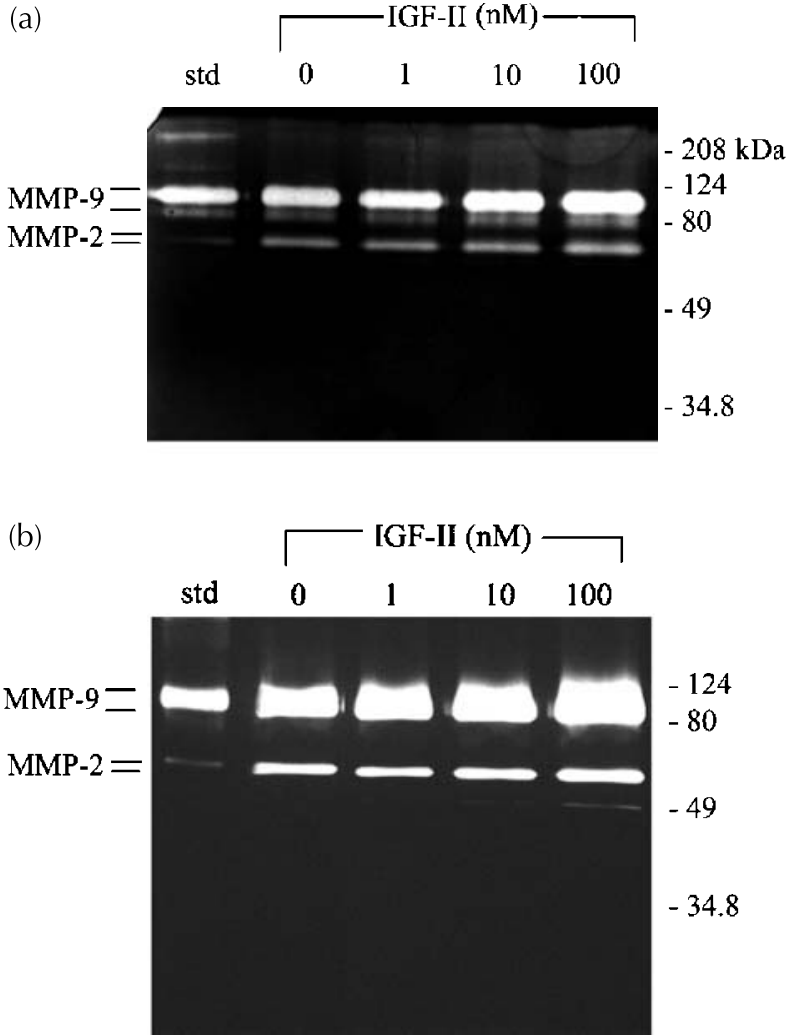

Figure 3 Zymograph gel showing MMP-2 and MMP-9 released from enriched VCT from (a) first trimester or (b) term placenta after $96 \mathrm{~h}$. The volume of medium added was corrected for the cell numbers present. Cells were incubated with IGF-II as shown. MMP standards were present in lane 1.

term VCT (Fig. 5b) generally reflected the overall changes in MMP activity, in that IGF-I and IGF-II had modest stimulatory effects at $100 \mathrm{nM}$, whereas nIGFBP-1 $(10 \mathrm{nM})$ and pIGFBP-1 $(1 \mathrm{nM})$ had more effect at lower levels. The highest concentration of pIGFBP-1 inhibited MMP-2 activity (Fig. 5b). Only nIGFBP-1 significantly increased MMP-9 activity in term VCT (Fig. 5c). The IGFs had modest stimulatory effects, but these did not reach statistical significance and pIGFBP-1 had little effect at any concentration (Fig. 5c).

Combinations of IGFs with IGFBP-1 had no overall effect on gelatinase production compared with the IGFs alone (results not shown). This applies to both first trimester and term VCT.

\section{Discussion}

For these studies we were able to generate a highly enriched population of VCT ( $\geq 95 \%$ cytokeratin 7 positive) from first trimester and term placentae. Numbers of contaminating cells remained low during the culture 
(a)
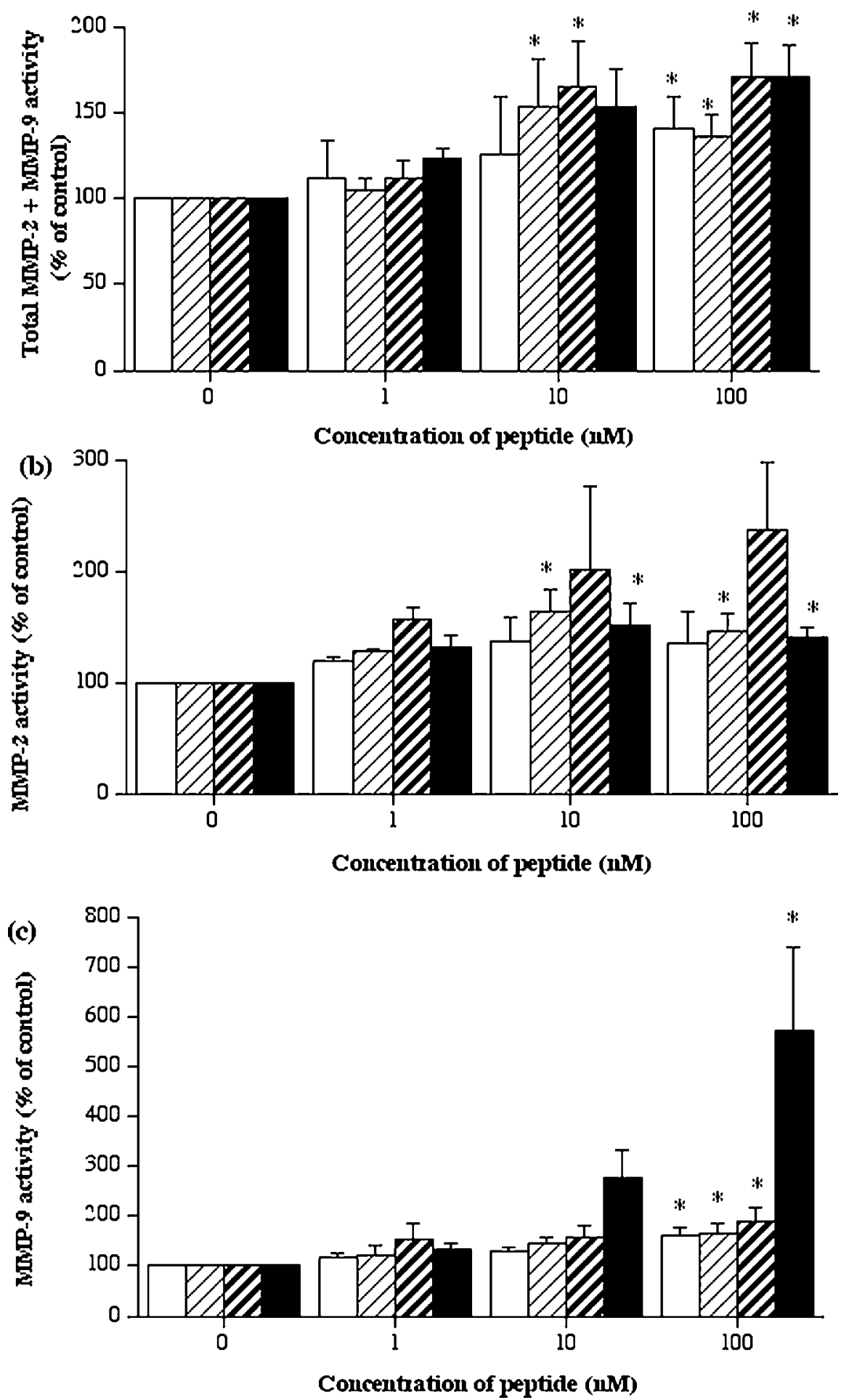

Figure 4 Effects of IGF-I ( $\square$ ), IGF-II (light hatched), nIGFBP-1 (heavy hatched) or pIGFBP-1 on gelatinase activity released from enriched first trimester VCT after $96 \mathrm{~h}$ of culture. Total (MMP-2+MMP-9) (a), MMP-2 (b) and MMP-9 (c) activity are shown. All data are means \pm S.E.M. $(n=4-6) .{ }^{*} P<0.05$ vs control (medium alone). 

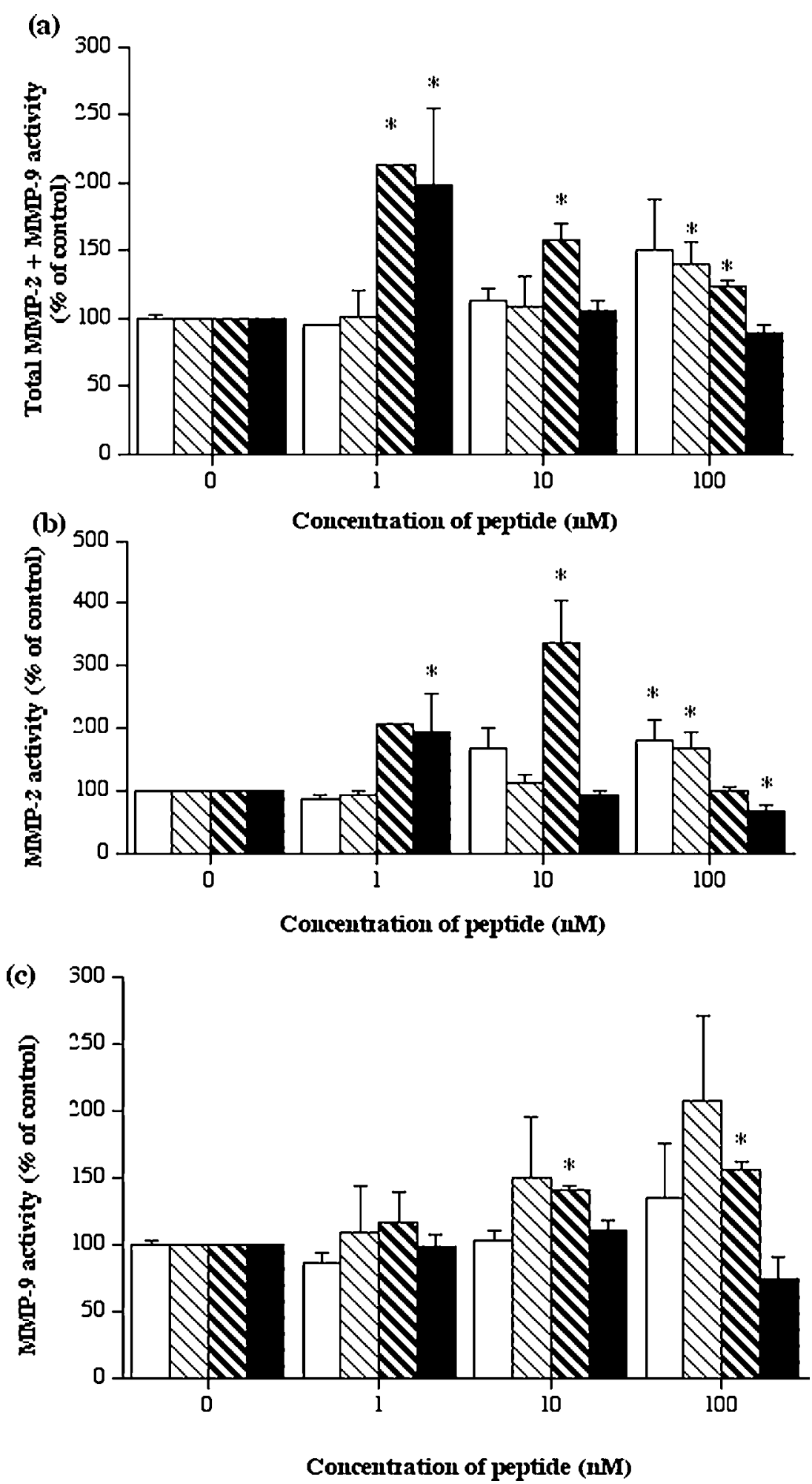

Figure 5 Effects of IGF-I ( $\square$ ), IGF-II (light hatched), nIGFBP-1 (heavy hatched) or pIGFBP-1 ( $)$ on gelatinase activity released from enriched term VCT after $96 \mathrm{~h}$ of culture. Total (MMP-2+MMP-9) (a), MMP-2 (b) and MMP-9 (c) activity are shown. All data are means \pm S.E.M. $(n=4-6) .{ }^{*} P<0 \cdot 05$ vs control (medium alone). 
Table 1 Summary of the effects of IGF family proteins on human VCT in vitro

\begin{tabular}{|c|c|c|c|c|c|}
\hline & IGF-I & IGF-II & nIGFBP-1 & pIGFBP-1 & Trimester \\
\hline Cell numbers & $\begin{array}{l}+(\mathrm{H}) \\
0\end{array}$ & $\begin{array}{l}++(\mathrm{H}) \\
0\end{array}$ & $\begin{array}{l}++(\mathrm{L}) \\
+(\mathrm{H})\end{array}$ & $\begin{array}{l}++(\mathrm{L}) \\
+(\mathrm{H})\end{array}$ & $\begin{array}{l}\text { 1st trimester } \\
\text { 3rd trimester }\end{array}$ \\
\hline MMPs & $\begin{array}{l}+(H) \\
0\end{array}$ & $\begin{array}{l}+(\mathrm{H}) \\
0\end{array}$ & $\begin{array}{l}+(\mathrm{H}) \\
+(\mathrm{L})\end{array}$ & $\begin{array}{l}+(\mathrm{H}) \\
+(\mathrm{L})\end{array}$ & $\begin{array}{l}\text { 1st trimester } \\
\text { 3rd trimester }\end{array}$ \\
\hline
\end{tabular}

0: no effect; +: moderate positive effect; ++: strong positive effect. (H): high dose optimal. (L) low dose optimal.

period, thus bypassing the problems of contamination which can complicate such long-term experiments (Choy \& Manyonda 1998). The VCT remained viable for at least $96 \mathrm{~h}$ of culture and the small-scale methods used to estimate cell numbers produced reliable data. The purity of the preparation and culture characteristics are comparable with those of Guilbert et al. (2002) who also obtained highly enriched villous cells. Others have used similar negative selection methods to generate and to characterise villous cells from term placentae (Douglas \& King 1989, Morrish et al. 1991, Yui et al. 1994, Aboagye-Mathiesen et al. 1996), but there are few studies on the functional regulation of these VCT.

Our findings are summarised in Table 1. This demonstrates clearly that the IGFs, most notably IGF-II, regulate only first trimester VCT and that the highest concentrations used $(100 \mathrm{nM})$ are most effective. This applies to cell numbers and to MMP production. While the former observation is not surprising, as VCT cells are known to proliferate, the latter finding was unexpected as villous cells are not thought to be invasive. It must be noted that MMP-1 (interstitial collagenase) (Moll \& Lane 1990) and MMP-9 (Isaka et al. 2002) have been detected in VCT of intact villi, and the latter is consistent with high levels of MMP-9 detected in our VCT (Fig. 3). The functional significance of the MMPs in VCT requires further investigation. It is well established that the placental expression of IGF-II declines with pregnancy (Han et al. 1996). This decline could be linked to the altered in vitro responses that we have found, but further studies are needed to identify the mechanism.

Both phosphoisoforms of IGFBP-1 affected VCT from first and third trimester placentae and the effects varied with gestational age. Low concentrations $(\sim 1 \mathrm{nM})$ of IGFBP-1 had the greatest effect on first trimester cell numbers (Table 1, Fig. 1a), whereas high concentrations affected MMP production (Table 1, Fig. 4). The exact opposite of this applied to term VCT, in that high concentrations of IGFBP-1 were needed to increase cell numbers and lower concentrations affected MMP levels (Table 1, Figs $1 \mathrm{~b}$ and 5). Neither of the IGFBP-1 isoforms inhibited the effects of IGF-II (Fig. 2c) on first trimester cells, indicating that the effects of the binding protein are not mediated through inhibition of the effects of IGFs.
In other systems, IGFBP-1 is known to bind to the Arg-Gly-Asp (RGD) sequence of $\alpha_{5} \beta_{1}$ integrin, and thereby regulate cell functions (Gleeson et al. 2001). It is not clear if this applies to VCT as these cells are generally $\alpha_{5}$ negative (Bischof et al. 1993). Also, the differential effects of different concentrations of IGFBP-1 on cell numbers and on MMPs indicate that two different signalling pathways are involved. Finally, the effects of IGFBP-1 on VCT change with gestational age (Table 1). A simplistic interpretation would suggest that decidual IGFBP-1 would support VCT proliferation and invasive potential (MMPs) at all gestational ages. However, it could be argued that the levels of IGFBP-1 that would reach the VCT would be relatively low, given that the cells are physically distant from the main source of IGFBP-1 (the decidua) and the syncytium interposes between the maternal blood and the VCT. Under such conditions, IGFBP-1 would mainly support the proliferation of VCT in the first trimester, and maintain invasive potential in the third trimester.

While some studies have implicated IGFBP-1 in the inhibition of placental or fetal development (Howell et al. 1989, Giudice et al. 1995), other data show that IGFBP1 has positive effects. Overexpression of human IGFBP-1 in the decidua of transgenic mice increased placental size (Crossey et al. 2002), suggesting that in murine pregnancy IGFBP-1 supports placental development. Gratton et al. (2002) have reported that IGFBP-1 expression in human decidua was decreased in women suffering from preeclampsia, a disorder characterised by defective placentation. Again, this indicates that IGFBP-1 supports placental development rather than decreasing it, which is consistent with our findings. In a culture system of term human trophoblast, pIGFBP-1 inhibited IGF-I-stimulated uptake of an amino acid ( $\mathrm{Yu}$ et al. 1998), whereas nIGFBP-1 potentiated the effect of IGF-I. Establishing the mechanism of action of IGFBP-1 isoforms in human VCT would help in resolving these differences.

Our data cannot discriminate between increased trophoblast proliferation or decreased apoptosis (increased cell survival), so we cannot state that IGFs or IGFBP-1 increased proliferation of these cells. A recent paper (Smith et al. 2002) has shown that IGF-I is a survival factor for third trimester trophoblast cells at a concentration of 
$2.7 \mathrm{nM}$, which is consistent with our findings of increased cell numbers at similar concentrations $(1-10 \mathrm{nM})$. The impact of IGF-II on first trimester trophoblast survival has yet to be assessed. Future studies should be planned to discriminate between changes in apoptosis and in cell proliferation.

Taken together, our findings expand the previous data on a role for the IGF-IGFBP-1 axis in human pregnancy (Maruo et al. 1995, Han et al. 1996, Li \& Zhuang 1997, Hamilton et al. 1998) to include the villous trophoblast cell population. Others have shown that IGF-II is a more potent regulator than IGF-I of placental function (Hamilton et al. 1998), but there are few precedents for the positive effects of IGFBP-1, which require further study.

\section{Acknowledgements}

The authors would like to thank Action Research and SPARKS (FAH) for supporting this work. The authors declare that there is no conflict of interest that would prejudice the impartiality of this scientific work.

\section{References}

Aboagye-Mathiesen G, Laugesen J, Zdravkovic M \& Ebbesen P 1996 Isolation and characterization of human placental trophoblast subpopulations from first trimester chorionic villi. Clinical and Diagnostic Laboratory Immunology 3 14-22.

Anim-Nyame N, Hills FA, Sooranna SR, Steer PJ \& Johnson MR 2000 A longitudinal study of maternal plasma insulin-like growth factor binding protein-1 concentrations during normal pregnancy and pregnancies complicated by pre-eclampsia. Human Reproduction 15 2215-2219.

Barker DJ, Gluckman PD, Godfrey KM, Harding JE, Owens JA \& Robinson JS 1993 Fetal nutrition and cardiovascular disease in adult life. Lancet 341 938-941.

Barton SC, Adams CA, Norris ML \& Surani MA 1985 Development of gynogenetic and parthenogenetic inner cell mass and trophectoderm tissues in reconstituted blastocysts in the mouse. Journal of Embryology and Experimental Morphology 90 267-285.

Bischof P, Redard M, Gindre P, Vassilakos P \& Campana A 1993 Localization of alpha 2, alpha 5 and alpha 6 integrin subunits in human endometrium, decidua and trophoblast. European Journal of Obstetrics Gynecology and Reproductive Biology 51 217-226.

Bischof P, Martelli M, Campana A, Itoh Y, Ogata Y \& Nagase H 1995 Importance of matrix metalloproteinases in human trophoblast invasion. Early Pregnancy 1 263-269.

Brosens IA, Robertson WB and Dixon HG 1972 The role of spiral arteries in the pathogenesis of preeclampsia. Obstetrics and Gynecology Annual 1 177-191.

Chakraborty C, Gleeson LM, McKinnon T \& Lala PK 2002 Regulation of human trophoblast migration and invasiveness. Canadian Journal of Physiology and Pharmacology 80 116-124.

Choy MY \& Manyonda IT 1998 The phagocytic activity of human first trimester extravillous trophoblast. Human Reproduction 13 2941-2949.

Crossey PA, Pillai CC \& Miell JP 2002 Altered placental development and intrauterine growth restriction in IGF binding protein-1 transgenic mice. Journal of Clinical Investigation 110 411-418.

Douglas GC \& King BF 1989 Isolation of pure villous cytotrophoblast from term human placenta using immunomagnetic microspheres. Journal of Immunological Methods 119 259-268.
Giudice LC, de Zegher F, Gargosky SE, Dsupin BA, de las Fuentes L, Crystal RA, Hintz RL \& Rosenfeld RG 1995 Insulin-like growth factors and their binding proteins in the term and preterm human fetus and neonate with normal and extremes of intrauterine growth. Journal of Clinical Endocrinology and Metabolism $\mathbf{8 0}$ $1548-1555$.

Gleeson LM, Chakraborty C, McKinnon T \& Lala PK 2001 Insulin-like growth factor-binding protein-1 stimulates human trophoblast migration by signalling through $\alpha 5 \beta 1$ integrin via mitogen-activated protein kinase pathway. Journal of Clinical Endocrinology and Metabolism 86 2484-2493.

Graham CH \& Lala PK 1992 Mechanisms of placental invasion of the uterus and their control. Biochemistry and Cell Biology 70 867-874.

Graham CH, Lysiak JJ, McCrae KR \& Lala PK 1992 Localization of transforming growth factor-beta at the human fetal-maternal interface: role in trophoblast growth and differentiation. Biology of Reproduction 46 561-572.

Graham CH, Hawley TS, Hawley RG, MacDougall JR, Kerbel RS, Khoo N \& Lala PK 1993 Establishment and characterization of first trimester human trophoblast cells with extended lifespan. Experimental Cell Research 206 204-211.

Gratton RJ, Asano H \& Han VKM 2002 The regional expression of insulin-like growth factor II (IGF-II) and insulin-like growth factor binding protein-1 (IGFBP-1) in the placentae of women with pre-eclampsia. Placenta 23 303-310.

Guilbert LJ, Winkler-Lowen B, Sherburne R, Rote NS, Li H \& Morrish DW 2002 Preparation and functional characterization of villous cytotrophoblasts free of syncytial fragments. Placenta $\mathbf{2 3}$ 175-183.

Haigh T, Chen C-P, Jones CJP \& Aplin JD 1999 Studies of mesenchymal cells from 1st trimester human placenta: expression of cytokeratin outside the trophoblast lineage. Placenta 20 615-625.

Hamilton GS, Lysiak JJ, Han VK \& Lala PK 1998 Autocrineparacrine regulation of human trophoblast invasiveness by insulin-like growth factor (IGF)-II and IGF-binding protein (IGFBP)-1. Experimental Cell Research 10 147-156.

Han VKM, Bassett N, Walton J \& Challis JRG 1996 The expression of insulin-like growth factor (IGF) and IGF binding protein (IGFBP) genes in the human placenta and membranes: evidence for IGF-IGFBP-interactions at the feto-maternal interface. Journal of Clinical Endocrinology and Metabolism 81 2680-2693.

Hills FA \& Chard T 1995 Insulin-like growth factors and their binding proteins in the control of fetal growth. Contemporary Reviews in Obstetrics and Gynecology 7 1-8.

Howell RJ, Economides D, Teisner B, Farkas AG \& Chard T 1989 Placental proteins 12 and 14 in pre-eclampsia. Acta Obstetrica et Gynecologica Scandinavica 68 237-240.

Hustin J, Jauniaux E \& Schaaps JP 1990 Histological study of the materno-embryonic interface in spontaneous abortion. Placenta 11 477-486.

Irwin JC \& Giudice LC 1998 Insulin-like growth factor binding protein-1 binds to placental cytotrophoblast $\alpha_{5} \beta_{1}$ integrin and inhibits cytotrophoblast invasion into decidualized endometrial cultures. Growth Hormorne and IGF Research 8 21-31.

Isaka K, Usuda S, Ito H, Sagawa Y, Nakamura H, Nishi H, Suzuki Y, Li YF \& Takayama M 2002 Expression and activity of matrix metalloproteinase 2 and 9 in human trophoblasts. Placenta 24 53-64.

Jones JI \& Clemmons DR 1995 Insulin-like growth factors and their binding proteins: biological actions. Endocrine Reviews 16 3-34.

Jones JI, D'Ercole AJ, Camacho-Hubner C \& Clemmons DR 1991 Phosphorylation of insulin-like growth factor (IGF)-binding protein 1 in cell culture and in vivo: effects on affinity for IGF-I. PNAS $\mathbf{8 8}$ 7481-7485.

Jones JI, Gockerman A, Busby WH, Camacho-Hubner C \& Clemmons DR 1993a Extracellular matrix contains insulin-like growth factor binding protein-5: potentiation of the effects of IGF-I. Journal of Cell Biology 121 679-687. 
Jones JI, Gockerman A, Busby WH, Wright G \& Clemmons DR $1993 b$ Insulin-like growth factor binding protein 1 stimulates cell migration and binds to the alpha 5 beta 1 integrin by means of its Arg-Gly-Asp sequence. PNAS 90 10553-10557.

Lala PK, Lee BP, Xu G \& Chakraborty C 2002 Human placental trophoblast as an in vitro model for tumor progression. Canadian Journal of Physiology and Pharmacology 80 142-149.

Lata JA, Tuan RS, Shepley KJ, Mulligan MM, Jackson LG \& Smith JB 1992 Localization of major histocompatibility complex class I and II mRNA in human first-trimester chorionic villi by in situ hybridization. Journal of Experimental Medicine 175 1027-1032.

Lewis MP, Morlese JF, Sullivan MHF \& Elder MG 1993 Evidence for decidua-trophoblast interactions in early human pregnancy. Human Reproduction 8 965-968.

Lewis MP, Clements M, Takeda S, Kirby PL, Seki H, Lonsdale LB, Sullivan MHF, Elder MG \& White JO 1996 Partial characterisation of an immortalised trophoblast cell line, TCL-1, which possesses a CSF-1 autocrine loop. Placenta 17 137-146.

Li RH \& Zhuang LZ 1997 The effects of growth factors on normal human placental cytotrophoblast cell proliferation. Human Reproduction 12 830-834.

Librach CL, Werb Z, Fitzgerald ML, Chiu K, Corwin NM, Esteves RA, Grobelny D, Galardy R, Damsky CH \& Fisher SJ 1991 92-kD type IV collagenase mediates invasion of human cytotrophoblasts. Journal of Cell Biology 113 437-449.

McKinnon T, Chakraborty C, Gleeson LM, Chidac P \& Lala PK 2001 Stimulation of human extravillous trophoblast migration by IGF-II is mediated by IGF type 2 receptor involving inhibitory G protein(s) and phosphorylation of MAPK. Journal of Clinical Endocrinology and Metabolism 86 3665-3674.

Maruo T, Murata K, Matsuo H, Samoto T \& Mochizuki M 1995 Insulin-like growth factor-I as a local regulator of proliferation and differentiated function of human trophoblast in early pregnancy. Early Pregnancy 1 54-61.

Moll UM \& Lane BL 1990 Proteolytic activity of first trimester human placenta: localization of interstitial collagenase in villous and extravillous trophoblast. Histochemistry 94 555-560.

Morison JE 1978 Placenta accreta. A clinicopathologic review of 67 cases. Obstetrics and Gynecology Annual 7 107-123.

Morrish DW, Shaw ARE, Seehafer J, Bhardwaj D \& Paras MT 1991 Preparation of fibroblast-free cytotrophoblast cultures utilizing differential expression of the CD9 antigen. In Vitro Cellular and Developmental Biology 27A 303-306.

Nielsen FC 1992 The molecular and cellular biology of insulin-like growth factor II. Progress in Growth Factor Research 4 257-290.

Okamoto T \& Nishimoto I 1991 Analysis of stimulation-G protein subunit coupling by using active IGF-II receptor peptide. PNAS $\mathbf{8 8}$ 8020-8023.

Paradinas FJ \& Fisher RA 1995 Pathology and molecular genetics of trophoblastic disease. Current Opinion in Obstetrics and Gynecology $\mathbf{5}$ 6-12.
Pekonen F, Suikkari AM, Makinen T \& Rutanen EM 1988 Different insulin-like growth factor binding species in human placenta and decidua. Journal of Clinical Endocrinology and Metabolism 67 $1250-1257$.

Rice A \& Chard T 1998 Cytokines in implantation. Cytokine and Growth Factor Reviews 9 287-296.

Ritvos O, Ranta T, Jalkanen J, Suikkari AM, Voutilainen R, Bohn H \& Rutanen EM 1988 Insulin-like growth factor (IGF) binding proteins from human decidua inhibits the biological action of IGF-I in cultured choriocarcinoma cells. Endocrinology 122 2150-2157.

Robertson WB, Brosens I \& Dixon G 1975 Uteroplacental vascular pathology. European Journal of Obstetrics Gynecology and Reproductive Biology 5 47-65.

Rutanen E-M, Koistinen R, Wahlstrom T, Bohn H, Ranta T \& Seppala M 1985 Synthesis of placental protein 12 by human decidua. Endocrinology 116 1304-1309.

Sanchez-Cuenca J, Martin JC, Pellicer A \& Simon C 1999 Cytokine pleiotropy and redundancy-gp130 cytokines in human implantation. Immunology Today 20 57-59.

Sharkey AM, Dellow K, Blayney M, MacNamee M, Charnock-Jones S \& Smith SK 1995 Stage-specific expression of cytokine and receptor mRNA in human preimplantation embryos. Biology of Reproduction 54 974-981.

Smith S, Francis R, Guilbert L \& Baker PN 2002 Growth factor rescue of cytokine mediated trophoblast apoptosis. Placenta $\mathbf{2 3}$ 322-330.

Steele-Perkins G, Turner J, Edman JC, Hari J, Pierce SB, Stover C, Rutter WJ \& Roth RA 1988 Expression and characterization of a functional human insulin-like growth factor I receptor. Journal of Biological Chemistry 263 11486-11492.

Surani MA, Barton SC \& Norris ML 1987 Influence of parental chromosomes on spatial pathology in androgenetic-parthenogenetic chimaeras in the mouse. Nature 326 395-397.

Teasdale F 1989 Histomorphometry of the human placenta in pre-eclampsia associated with severe intrauterine growth retardation. Placenta 8 119-128.

Yu J, Iwashita M, Kudo Y \& Takeda Y 1998 Phosphorylated insulin-like growth factor (IGF)-binding protein-1 (IGFBP-1) inhibits while non-phosphorylated IGFBP-1 stimulates IGF-I-induced amino acid uptake by cultured trophoblast cells. Growth Hormone and IGF Research 8 65-70.

Yui J, Garcia-Lloret M, Brown AJ, Berdan RC, Morrish DW, Wegmann TG \& Guilbert LJ. 1994 Functional, long-term trophoblasts purified by column-elimination of CD9 expressing cells. Placenta 15 231-246.

Received 24 June 2004

Accepted 24 August 2004

Made available online as an

Accepted Preprint 9 September 2004 